\title{
THE ROLE OF REASONABLENESS IN THE REVIEW OF LABOUR ARBITRATON AWARDS (PART 1)
}

\author{
Carli Botma
}

LLB LLM

Attorney, Francois le Roux Attorneys

Research Associate:

Labour and Social Security Law Unit

Nelson Mandela Metropolitan University

Port Elizabeth

\section{Adriaan van der Walt \\ Bluris BA(Hons) LLB \\ Associate Professor}

Head: Labour and Social Security Law Unit

Nelson Mandela Metropolitan University

Port Elizabeth

\section{SUMMARY}

This article is published in two parts. In the first part (published in this edition of Obiter) the authors establish the general principles relating to administrative review and consider the different forms of review. Thereafter CCMA arbitration award reviews are considered. As is characteristic of special statutory reviews the Labour Relations Act, 1995 ("the LRA") makes specific provision for the review of CCMA arbitration awards. The grounds of review are presented in such a manner that it has the effect of limiting the ambit. The administrative nature of CCMA arbitrations is considered. It is pointed out that the courts regard the CCMA as organ of state and that the rendering of an arbitration award is considered as the commission of an administrative act that is subject to the constitutional imperatives of the administrative justice right of the Constitution.

The authors also establish that the courts have not interpreted the restrictive scope of section 145 of the LRA as falling foul of the constitutional right to administrative justice. Rather, the courts have reasoned that, when reading section 145 in light of the constitutional right to administrative justice, the alleged misconduct, gross irregularity, exceeding of powers or impropriety as the case may be need only be measured against the constitutional imperatives of the administrative justice right in order to ensure constitutional consistency. So construed, an arbitration award would be reviewable if the reviewing court is able to conclude that the commissioner has 
committed misconduct or a gross irregularity or has exceeded his powers in terms of section 145(2) of the LRA because the decision is not justifiable in terms of the reasons given. The award would, however, not be reviewable only because it is perceived to be unjustifiable per se; the justifiability must be attributed to one or more of the statutory grounds of review found in section 145(2) of the LRA.

In Part 2 of the article the effect of the judgment of the Constitutional Court in Sidumo v Rustenburg Platinum Mines Ltd 200712 BLLR 1097 (CC) will be analysed as well as the application of the principles established in Sidumo in subsequent case law. Finally the reasonableness standard and private arbitration reviews will be considered. Part 2 will be published in the following edition of Obiter.

\section{$1 \quad$ INTRODUCTION}

The remedy of review is not unique to the South African labour law system, nor otherwise foreign to South African law, but has long since been recognised as a means to challenge the decisions or proceedings of inferior courts, both civil and criminal, as well as those of tribunals or boards whether it performs judicial, quasi-judicial or administrative functions. This is illustrated by among others section 24 of the Supreme Court Act 59 of 1959 and section 302 of the Criminal Procedure Act 51 of $1977 .{ }^{1}$ Where review is the procedure prescribed, courts are not required to re-hear evidence or information previously before a lower court or tribunal in order to determine whether such a court or tribunal was correct in its finding. ${ }^{2}$ Courts on review are simply required to determine whether the method whereby the result was obtained, is acceptable. As such, reviews hold advantages for both litigants to a dispute: Not only does the limited grounds for review safeguard reviews from being instituted on the whims of prospective litigants, hindering unsubstantiated claims, but because a review is limited to the record of proceedings, it is also considered to be a more expeditious and less expensive mechanism for challenging unsatisfactory decisions or proceedings. $^{3}$

With the adoption of the Labour Relations Act 66 of $1995^{4}$ and the establishment of the Commission for Conciliation, Mediation and Arbitration, ${ }^{5}$ the legislature attempted to introduce mechanisms to ensure the speedy, cost-effective and final resolution of labour disputes. That such objectives were set is apparent in various sections of the LRA: section 1 identifies "the effective resolution of labour disputes" as one of the primary objectives of the LRA; section 138 specifies that a commissioner may conduct an arbitration in such a manner so as to "determine the dispute fairly and quickly" and, in terms of section 143(1), an arbitration award is "final and binding and may be enforced as if it were an order of the labour court". However, while common sense dictates the necessity of finally resolving

\footnotetext{
See par 23 below.

See par 22 below.

See par 3 below.

Hereinafter "the LRA".

Hereinafter "the CCMA".
} 
disputes at arbitration level, it would be foolish not to acknowledge that arbitrators are also mere mortals capable of making mistakes. Consequently, a concession that some mechanism is required to challenge defective arbitration awards is not unrealistic; neither is a concession that extensive mechanisms for challenging arbitration awards will inhibit any contemplation of the speedy resolution of disputes. It is thus not surprising that the less extensive and/or intrusive characteristics of the review remedy appealed to the legislature; resulting in its decision to follow this so-called "golden middle way" and introduce the concept of review to the labour court ${ }^{7}$ as a means of challenging defective arbitration awards.

As positive as it may sound, the LRA's remedy of review is not without concerns of its own. Section 145 of the LRA, although expressly empowering the labour court to review arbitration awards, is not open-ended in its recognition of the grounds for review, and case law demonstrates that employers and employees, dissatisfied with the outcome of arbitration awards for reasons not contemplated in section 145, continuously seek opportunities to challenge arbitration awards on grounds which can either be regarded by some as stretching the meaning of section 145 or falling outside the ambit of section $145 .^{8}$ More particularly, case law bears witness of employers' and employees' attempts to review awards in terms of section $158(1)(\mathrm{g})$ of the LRA in so far as it provides for the remedy of review without any similar restriction as to the grounds of review. In a similar manner, they have sought to broaden the grounds of review by alleging that arbitrators engage in administrative action; justifying their initial reliance on the justifiability and reasonableness principles as provided for in the Constitution of the Republic of South Africa Act 200 of $1993^{9}$ and the Constitution of the Republic of South Africa, $1996^{10}$ respectively and, since the introduction of the Promotion of Administrative Justice Act 3 of $2000,{ }^{11}$ the open-ended grounds of review provided for in section 6(2). ${ }^{12}$ These are but some of the contentions that the courts have been confronted with when performing their review function and, if it does not constitute sufficient cause to investigate the review of arbitration awards, a quick perusal of Carephone (Pty) Ltd $v$ Marcus NO, ${ }^{13}$ Toyota South Africa Motors (Pty) Ltd v Radebe, ${ }^{14}$ Shoprite Checkers (Pty) Ltd $v$ Ramdaw NO, ${ }^{15}$ and the more recent cases of Sidumo $v$ Rustenburg Platinum Mines Ltd ${ }^{16}$ and Fidelity Cash Management Service $v$

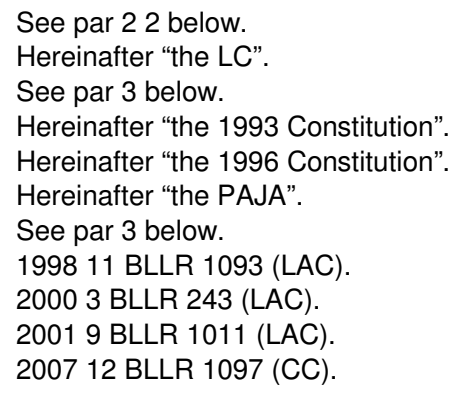


$C C M A^{17}$ and the divergent opinions expressed therein will further demonstrate the relevance of such a study.

With the above as background and with the objective of determining the role played by reasonableness in the review of labour arbitration awards, the courts' exposition of the proper approach to follow in the exercise of their review function will be discussed herein as follows: In paragraph 2, the nature and purpose of the remedy of review will be explained and distinguished from an appeal in order to demonstrate the importance of scrutinising on review the manner in which the decision was arrived at and, ancillary hereto, to identify how best to approach the merits of the matter. The types of review generally provided for in South African law will also be identified to illustrate how and where the review of labour arbitration awards fit into the review structure.

In paragraph 3 it will be considered whether litigants can bring review applications in terms of section $158(1)(\mathrm{g})$ of the LRA rather than section 145, particularly in those instances where their "ground(s)" of review identified fall beyond the compass of section 145. It will also be considered whether the CCMA function of making arbitration awards can be classified as administrative action that will entitle the applicant on review to rely on the more extensive grounds for review contained in the PAJA to review arbitration awards. Ancillary hereto, the courts' approach to arbitration award reviews in light of the justifiability principle contained in the 1993 Constitution will also be discussed in order to extract principles to assist in the interpretation of the findings made in the precedent setting judgment handed down by the constitutional court ${ }^{18}$ in Sidumo.

The key findings of the CC in Sidumo, the explication of the principles established by Sidumo in the Labour Court and Labour Appeal Court and the effect of Sidumo on private arbitration awards will be considered in the following edition of Obiter.

\section{GENERAL PRINCIPLES RELATING TO REVIEW}

\section{Definition and function of review distinguished from appeal}

Before discussing the role of reasonableness in the review of labour arbitration awards, it is necessary firstly to understand what is meant by the concept of review as opposed to an appeal. Albeit within the context of administrative law, Wade and Forsyth provide an explanation that, it is submitted, is suitable for current purposes: ${ }^{19}$

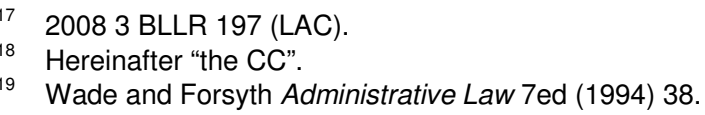


"The system of judicial review is radically different from the system of appeals. When hearing an appeal the court is concerned with the merits of the decision under appeal. When subjecting some administrative act or order to judicial review, the court is concerned with its legality. On an appeal the question is 'right or wrong'? On review the question is 'lawful or unlawful'?"

Also in Lekota $v$ First National Bank of SA $L t d,{ }^{20}$ the LC explained the function of review as follows:

"It is not the function of the reviewing court when reviewing an arbitration award in terms of section 145 of the Act to decide whether the commissioner acted correctly or (from the applicant's point of view) whether the decision by the commissioner was wrong. The defects that have to be shown in terms of section 145(2) of the Act (discussed above) is that either the commissioner (1) committed misconduct in relation to the duties of the commissioner as an arbitrator (this clearly would require a mala fide act on the part of the commissioner; (2) committed a gross irregularity in the conduct of the arbitration proceedings (this clearly has to do with the conduct of the arbitration proceedings in terms of which a gross irregularity occurs); and (3) that the commissioner exceeded his or her powers."

On this interpretation, a court on review is only required to determine the legality of a decision, the focus being procedural propriety ${ }^{21}$ and may not enquire whether a decision on the facts or the law was correctly found or interpreted. An appeal, on the other hand, will entail the court re-hearing the merits of the matter in order to determine whether the decision of the court a quo was right or wrong. ${ }^{22}$ This distinction has, however, been criticised for constituting a false portrayal of what the courts do on review; the contention being that judges are often influenced by the merits of a matter when deciding whether or not to exercise their power to review. ${ }^{23}$

When considering such critique in light of the reviews conducted by the LC, it can also be accepted that the distinction in the field of labour law is not as clear cut as it would on first glance appear. In particular, litigants often argue that an award is reviewable in so far as the arbitrator's finding was not rationally connected to the evidence or information before him or that the arbitrator failed to apply his mind and consider the material evidence presented. Stocks Civil Engineering (Pty) Ltd v Rip NO ${ }^{24}$ is but one example wherein the LAC has held, within the context of a private arbitration, that in certain respects errors of law and fact are reviewable. Recognised reviewable errors of law include the arbitrator asking the wrong question, applying the wrong test, basing his decision on matters not prescribed for making his decision, and failing to apply his mind to the relevant issues in

\footnotetext{
199810 BLLR 1021 (LC) par 16.

See also Cheadle, Davis and Haysom South African Constitutional Law: The Bill of Rights (2002) 27-16.

22 Burns and Beukes Administrative Law under the 1996 Constitution 3ed (2006) 279.

23 Cheadle, Davis and Haysom 27-16.

2420023 BLLR 189 (LAC) par 37.
} 
accordance with the behest of the statute applicable. ${ }^{25}$ In Masstores (Pty) Ltd t/a Builders Warehouse $v$ CCMA, ${ }^{26}$ the court also found that an arbitrator's award, stating that the applicant employee had opposed a postponement application, while there never was such an opposition, constituted an error of fact, rendering the award reviewable as a procedural irregularity. ${ }^{27}$ Similarly, in Health \& Hygiene (Pty) Ltd $v$ YAWA NO, ${ }^{28}$ the court declined to review and set aside an arbitration award on the basis of an error of fact, not on the basis that an error of fact did not constitute a ground for review, but because there was, in the court's opinion, no fact that the arbitrator overlooked or matter that, had the arbitrator known about it, would have caused him to act differently. ${ }^{29}$

At first glance, it appears as if all of the above cases have extended the remedy of review beyond its initially perceived procedural boundaries, in so doing posing a threat to the LRA's objective of the quick, effective and final resolution of disputes. ${ }^{30}$ Hoexter also acknowledges, within the context of administrative law review, that a scrutiny of the merits does threaten the distinction between appeal and review, but contends that: ${ }^{31}$

"[l]t is, in fact, quite impossible to judge whether a decision is within the limits of reason or 'defensible' without looking closely at matters such as the information before the administrator, the weight given to various factors and the purpose sought to be achieved by the decision. Only cases decided on the narrowest and most technical of grounds will not entail such scrutiny ..."

A study of case law reveals that the courts also accept that a scrutiny of the merits is unavoidable. In Carephone (Pty) Ltd v Marcus NO, ${ }^{32}$ the court justified its examination of the merits as follows: ${ }^{33}$

"In determining whether administrative action is justifiable in terms of the reasons given for it, value judgments will have to be made which will, almost inevitably, involve the consideration of the 'merits' of the matter in some way or another. As long as the judge determining this issue is aware that he or she enters the merits not in order to substitute his or her own opinion on the correctness thereof, but to determine whether the outcome is rationally justifiable, the process will be in order."

25 Hira v Booysen 19924 SA 69 (A); and see also Gray Security Services (WC) Pty Ltd v Cloete NO 2000 JOL 5974 (LC).

2620066 BLLR 577 (LC).

27 Par 43.

282000 JOL 7042 (LC).

29 Par 28.

See par 1 above.

31 Hoexter Administrative Law (2007) 317.

32 Supra 1093.

33 Par 36 (authors' emphasis added). 
The court held further that: ${ }^{34}$

"This provision introduces a requirement of rationality in the merit or outcome of the administrative decision. This goes beyond mere procedural impropriety as a ground for review or irrationality only as evidence of procedural impropriety. But it would be wrong to read into this section an attempt to abolish the distinction between review and appeal ..."

Similarly in Telcordia Technologies Inc $v$ Telkom $S A,{ }^{35}$ Harms JA explained that it was not an error of law per se which rendered an award reviewable: ${ }^{36}$

"Errors of law can, no doubt, lead to gross irregularities in the conduct of the proceedings. Telcordia posed the example where an arbitrator, because of a misunderstanding of the audi principle, refuses to hear the one party. Although in such a case the error of law gives rise to the irregularity, the reviewable irregularity would be the refusal to hear that party, and not the error of law. Likewise, an error of law may lead an arbitrator to exceed his powers or to misconceive the nature of the inquiry and his duties in connection therewith."

In Stocks Civil Engineering Van Dijkhorst AJA also confirmed that an error of law or fact rendered an award reviewable only if it could be attributed to one of the statutory grounds for review: ${ }^{37}$

"A court is entitled on review to determine whether an arbitrator in fact functioned as arbitrator in the way that he upon his appointment impliedly undertook to do, namely by acting honestly, duly considering all the evidence before him and having due regard to the applicable legal principles. If he does this, but reaches the wrong conclusion, so be it. But if he does not and shirks his task, he does not function as an arbitrator and reneges on the agreement under which he was appointed. His award will then be tainted and reviewable. It is equally implicit in the agreement under which an arbitrator is appointed that he is fully cognisant with the extent of and limits to any discretion or powers he may have. If he is not and such ignorance impacts upon his award, he has not functioned properly and his award will be reviewable. An error of law or fact may be evidence of the above in given circumstances, but may in others merely be part of the incorrect reasoning leading to an incorrect result. In short, material malfunctioning is reviewable, a wrong result per se not (unless it evidences malfunctioning). If the malfunctioning is in relation to his duties, that would be misconduct by the arbitrator as it would be a breach of the implied terms of his appointment."

\section{Then in Sidumo, Ngcobo J confirmed as follows: ${ }^{38}$}

"[T]here may well be a fine line between a review and an appeal, in particular, where, as I will show later in this judgment, the reviewing court considers the reasons given by a tribunal, not to determine whether the result is correct, but to determine whether a gross irregularity occurred in the proceedings. At times, it may be difficult to draw the line. There is, however, a clear line and

\footnotetext{
Par 31-32 (authors' emphasis added).

20072 All SA 243 (SCA).

Par 69 (authors' emphasis added).

37 Par 52 (authors' emphasis added).

38 Par 244 (authors' emphasis added).
} 
this line must be maintained. The drafters of the LRA were mindful of the distinction between review and appeal and they wanted this distinction to be maintained. What they sought to introduce was 'a simple, quick, cheap and non-legalistic approach to the adjudication of unfair dismissals'."

It is submitted that the above cases clearly demonstrate that errors of fact or law are not per se grounds for taking an award on review. It is only when such an error of fact or law can be attributed to one or more of the statutory recognised grounds for review that an award would be reviewable. It would then, however, not be the error of fact or law that renders the award reviewable, but the procedural irregularity, misconduct or impropriety; with the error of fact or law merely serving as evidence of the former.

\section{Forms of review}

Upon an inspection of the South African law system, various types of review can be identified. Initially in Johannesburg Consolidated Investment Co v Johannesburg Town Council, ${ }^{39}$ Innes CJ identified three types of review, namely the review of the proceedings of inferior courts, the common law review of decisions of administrative authorities and a wider form of statutory review. Hoexter, however, contends that, because of developments, the initial forms of review have been expanded also to incorporate automatic review and judicial review in the constitutional and administrative law sense. ${ }^{40}$ The types of review are briefly referred to herein in order to identify under which type the review of labour arbitration awards are to be classified.

\section{Review of the proceedings of inferior courts}

Section 24 of the Supreme Court Act 59 of 1959 enables the high court, as a court of higher instance, to review the proceedings of the court a quo, such as the magistrates' court and small claims court, on the following grounds:

- Absence of jurisdiction by the court;

- interest in the cause, bias, malice or corruption by the presiding judicial officer;

- gross irregularity in the proceedings; and/or

- the admission of inadmissible or incompetent evidence or the rejection of admissible or competent evidence.

\section{Automatic review}

An example of this form of review is found in section 302 of the Criminal Procedure Act 51 of 1977. In terms of this section, certain sentences of the

1903 TS 111116

40 Hoexter 108. 
magistrates' courts must be reviewed by the provincial or local division of the high courts "in the ordinary course of events", without it being necessary for the accused to request it.

\section{Judicial review in the constitutional sense}

In terms of section 172(1)(a) of the 1996 Constitution, our courts are empowered to scrutinise law and conduct for the purpose of establishing whether these are consistent with its provisions and to declare them invalid to the extent of their inconsistency. As a result of the recognition of the right to just administrative action in section 33 of the 1996 Constitution, reviews within the administrative law sphere are largely regarded as a species of constitutional review. ${ }^{41}$

\section{Judicial review in the administrative law sense}

A more extensive discussion of this from of review is required in so far as it has bearing on the question whether the making of an arbitration award constitutes administrative action to which the standard of review, as exculpated in PAJA, applies.

\section{Common law or constitutional review}

Prior to the adoption of the 1993 and 1996 Constitution and later the PAJA, the high courts' ability to scrutinise and set aside administrative decisions or rules was based on the invocation of its inherent power of judicial review as provided for in terms of the common law. ${ }^{42}$ Parties dissatisfied with administrative action thus had to challenge administrative decisions on the basis of the grounds of review recognised at common law, mostly through trial and error by the courts, such as the ultra vires doctrine and the failure to comply with the rules of natural justice. ${ }^{43}$ With the introduction of the constitutional dispensation, the question arose whether the grounds applicable to the review of administrative action at common law have ceased to exist or whether these could still be invoked, causing the review to be treated as a common law rather than constitutional matter. Initially, this was a matter of controversy and in Commissioner for Customs and Excise $v$ Container Logistics (Pty) Ltd; Commissioner for Customs and Excise $v$ Rennies Group Ltd t/a Renfreight, ${ }^{44}$ the court found that the entrenched right to administrative justice, as contained in section 24 of the 1993 Constitution, could not have been intended to do away with the common law approach to

41 See par 2241 below.

42 Burns and Beukes 280; Hoexter 109; and see also Johannesburg Consolidated Investment Co v Johannesburg Town Council supra 111.

43 Burns and Beukes 59.

$44 \quad 19998$ BCLR 833 (SCA). 
review and that administrative review in its common law guise continued to exist alongside the constitutional regime, enabling the court to set aside the administrative act concerned without reference to section 24. However, in Pharmaceutical Manufacturers Association of SA In Re: Ex Parte Application of President of the $R S A,{ }^{45}$ the CC laid this matter to rest when Chaskalson $\mathrm{P}$ held that:

"The common-law principles that previously provided the grounds for judicial review of public power have been subsumed under the Constitution, and in so far as they might continue to be relevant to judicial review, they gain their force from the Constitution. In the judicial review of public power, the two are intertwined and do not constitute separate concepts."

In Bato Star Fishing (Pty) Ltd $v$ The Minister of Environmental Affairs and Tourism $^{46}$ O'Regan $\mathrm{J}$ referred to Pharmaceutical Manufacturers and confirmed that: ${ }^{47}$

"The grundnorm of administrative law is now to be found in the first place not in the doctrine of ultra vires, nor in the doctrine of parliamentary sovereignty, nor in the common law itself, but in the principles of our Constitution. The common law informs the provisions of PAJA and the Constitution, and derives its force from the latter. The extent to which the common law remains relevant to administrative review will have to be developed on a case-by-case basis as the courts interpret and apply the provisions of PAJA and the Constitution."

As a consequence, the judicial review of administrative action has obtained a constitutional basis which means that challenges to the validity of administrative action have to involve the direct application of section 33 of the 1996 Constitution and not the former common law grounds of review. ${ }^{48}$

\section{Review in terms of the PAJA}

Since the decision in Pharmaceutical Manufacturers, ${ }^{49}$ the legislature, however, further complicated matters with the promulgation of the PAJA, so as to give effect to the constitutional imperative contained in section 33(3) of the 1996 Constitution. Section 33(3) specifically provides that national legislation must be enacted to give effect to the right to just administrative action and that it must provide for the review of administrative action either by a court or independent and impartial tribunal. From the preamble of the PAJA it can be deduced that the PAJA is envisaged to be the "national legislation" referred to in section 33(3) of the 1996 Constitution and accordingly the primary or default pathway to the review of administrative action. That challenges to the validity of administrative action must be based on the grounds of judicial review laid down in section 6(2) of the PAJA, and

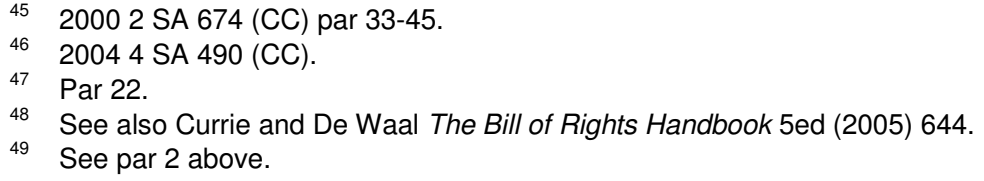


not directly on section 33(1) of the 1996 Constitution, ${ }^{50}$ was confirmed by the CC in Bato Star. ${ }^{51}$

"The cause of action for the judicial review of administrative action now ordinarily arises from PAJA, not from the common law as in the past. And the authority of PAJA to ground such causes of action rests squarely on the Constitution."

So construed, the constitutional right to just administrative action will mostly play an indirect role in judicial review, while direct constitutional review will be limited to instances not covered by the PAJA, for example where the PAJA, as ordinary legislation, is challenged on the basis that it limits the rights in section 33(1) unjustifiably. It is submitted that this becomes relevant when discussing the review of arbitration awards in terms of the LRA and when establishing the role of reasonableness in section 145 of the LRA.

\section{Special statutory review}

According to Hoexter, special statutory review refers to those instances where the legislature confers on the courts a statutory power of review as opposed to the "ordinary" judicial review as governed by the PAJA. ${ }^{52}$ Within the labour law context, the legislature, in an attempt to give effect to the constitutional obligations contained in section 27 of the 1993 Constitution, ${ }^{53}$ adopted section 145 of the LRA. It is submitted that the latter as well as section 33 of the AA constitutes a statutory power of review afforded to the LC in order to review statutory and private arbitration awards respectively.

\section{Conclusion}

In the above discussion it has been established that it is important to keep in mind the nature and purpose of review, especially when one seeks to determine the scope for reviewing an arbitration award and the role of reasonableness in particular. Unlike an appeal where the overturning of a decision is sought because the court a quo came to the wrong conclusion on the facts or the law, a review focuses on the process and the way in which the commissioner came to his conclusions and asks whether it shows that the decision was arrived at as a result of the commission of one or more of the section 145 grounds for review. The fact that the court on review is charged with determining whether a section 145 ground for review has occurred and not with the correctness of the outcome, does, however, not have the effect that the reviewing court may not have regard to the merits of the matter. The case law referred to above makes it apparent that a

\footnotetext{
See also PSA obo Haschke $v$ MEC for Agriculture 20048 BLLR 822 (LC) par 9.

Par 25.

Hoexter 109.

S 23 of the 1996 Constitution.
} 
contemplation of the merits is unavoidable on review. The only difficultly lies in determining to what extend and in what manner the merits of a particular case should be scrutinised. The courts seem to agree that the answer to this question also lies in the distinction between an appeal and review or, put differently, in the purpose for which the merits are considered. It has been established that, whereas on appeal the merits or reasons are considered to determine whether the finding is right or wrong, it is considered on review to determine whether one or more of the section 145 grounds for review can be identified as having occurred. When considering whether judicial intervention is appropriate in a given case the court should thus ask itself whether it wishes to interfere with the award because the merits, after scrutiny, reveal that the arbitration proceedings were defective on one or more of the recognised grounds for review or because it is of the opinion that it was the incorrect decision. In the first instance, the court will be entitled to review and set aside the award; in the latter not.

It further has been established that challenges to the validity of administrative action must in general be based on the grounds of judicial review laid down in section 6 of the PAJA, and not directly on section 33 of the 1996 Constitution or in terms of the courts' inherent power of review. It has, however, also been established that reviews in terms of the LRA and the AA fall within the confines of special statutory review as opposed to judicial review in the administrative law sense. This suggests that even if the making of an arbitration award does constitute administrative action, the provisions of the PAJA would not necessarily be applicable to the review thereof. ${ }^{54}$

\section{JUSTIFIABILITY AND CCMA ARBITRATION AWARD REVIEWS}

\section{Introduction}

As is characteristic of special statutory reviews, the LRA makes specific provision for the review of CCMA arbitration awards. However, as will be noted below, the grounds for review are prescribed in such a manner that it has the effect of limiting the ambit within which such arbitration awards are reviewable. This becomes problematic for employers and employees alike when they are dissatisfied with the outcome of an arbitration award but are unable to ascribe any of their dissatisfaction to any particular ground listed in section 145(2) of the LRA. As a result of the perceived constraints of section $145(2)$, our courts have continuously been confronted with innovative arguments designed to circumvent or expand upon the restricted grounds imposed thereby in order to secure the review of an award that would otherwise have fallen beyond the parameters of the LC's reviewing powers.

54 See par 1 in Part 2 of the following edition of Obiter. 
These include contentions that arbitration awards should be reviewable in terms of the broader provisions of section 158(1)(g) of the LRA or in terms of the justifiability concept found in the 1993 Constitution. The latter contention is based on the perception that the making of an arbitration award constitutes an administrative act to which the provisions of the right to lawful, procedurally fair and justifiable administrative action as contained in the 1993 Constitution would be applicable. In the process of attempting to answer these questions, the courts have ventured down various avenues, including weighing the making of CCMA arbitration awards against the definition of administrative action, and considering whether the CCMA can be described as an organ of state. Although it can retrospectively be said that the aspects referred to above have largely been resolved by the LAC in the case of Carephone and that the principles so established therein have become academic in light of the introduction of the 1996 Constitution, it is submitted that it remains relevant, if only for interpretation purposes, especially when the implications of the findings made in Sidumo are considered.

\section{The administrative nature of CCMA arbitrations}

In Carephone, the LAC had to determine whether the making of an arbitration award constitutes administrative action for the purpose of the administrative justice provision contained in the 1993 Constitution. In so doing, the court contemplated whether the CCMA could be described as an organ of state and held that: ${ }^{.5}$

"It is, nevertheless, a public institution created by statute. When it (through duly appointed commissioners - section 125 and 136 of the LRA) conducts compulsory arbitration in terms of the LRA this involves the exercise of a public power and function because it resolves disputes between parties in terms of the LRA without needing the consent of the parties. This makes the Commission an organ of state in terms of the Constitution (see the definition of 'organ of state' in section 239 of the Constitution). The important implication of this is that the Commission is bound directly by the Bill of Rights in the Constitution (see section 8(1) of the Constitution). It is also subject to the basic values and principles governing public administration (see section 195 (2)(b) of the Constitution)."

Froneman DJP rejected the contention that the judicial nature of a CCMA arbitration rendered it incapable of being classified as administrative action: ${ }^{56}$

"Administrative action may take many forms, even if judicial in nature, but the action remains administrative."

Also in Mkhize $v$ CCMA ${ }^{57}$ the LC held that the CCMA is a tribunal as envisaged in section 39 of the 1996 Constitution and that, in so far as it

55 Par 11-12.

56 Par 19. 
exercises public power and performs public function in terms of legislation, it is an organ of state as defined in section 239(b)(ii) of the 1996 Constitution.

It is submitted that the judgments referred to above reflect the courts' opinion that the compulsory arbitration function of the CCMA constitutes administrative action for purposes of that right as contained in the 1993 Constitution. In the light of such a conclusion, the review of arbitration awards issued under the auspices of the CCMA could arguably be influenced by the terms of the administrative justice provision contained in the 1993 Constitution and, upon the enactment of the PAJA, be reviewable in terms of the grounds of review identified in the latter Act. ${ }^{58}$ However, as was mentioned above, ${ }^{59}$ the legislature, in an attempt to give effect to the constitutional obligations contained in section 27 of the 1993 Constitution, ${ }^{60}$ adopted the LRA and more particularly section 145, establishing a special statutory review in terms of LRA rather than the 1993 Constitution and, so it is argued, the PAJA.

The correctness of such an argument will be addressed in paragraph 4 when this topic is discussed in more detail in light of the 1996 Constitution and the findings made by the CC in Sidumo.

\section{Conflict of opinion: section 145 or section 158(1)(g)}

Section $145(1)$ of the LRA provides that any party to a dispute who alleges that a defect exists in any arbitration proceedings may apply to the LC for an order setting aside the arbitration award. According to section 145(2) of the LRA a defect means:

"(a) that the commissioner

(i) committed misconduct in relation to the duties of the commissioner as an arbitrator;

(ii) committed a gross irregularity in the conduct of the arbitration proceedings; or

(iii) exceeded the commissioner's powers; or

(b) that an award has been improperly obtained."

The LRA also caters for the remedy of review in section 158(1)(g), which, prior to its amendment, provided that: ${ }^{6}$

"The Labour Court may, despite section 145, review the performance or purported performance of any function provided for in this Act or any act or omission of any person or body in terms of this Act on any grounds that are permissible in law."

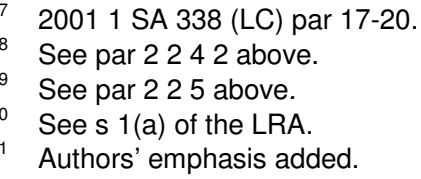


As a result of this wording, the debate ensued whether or not the broader grounds of review provided for in section 158(1)(g) had the effect of nullifying the narrower grounds of review applicable to arbitration awards in terms of section 145(2). Revelas $J$ first held in Edgars Stores (Pty) Ltd v Director, $C C M A^{62}$ that the review of arbitration awards of the CCMA should be on the narrow grounds provided for in section 145(2) of the LRA and that section 158(1)(g) was not applicable. ${ }^{63}$ Then, in Kynoch Feeds (Pty) Ltd v CCMA, ${ }^{64}$ Revelas $\mathrm{J}$ conceded that Edgars was wrongly decided and found that arbitration awards can be reviewed on the wider grounds for review contained in section $158(1)(\mathrm{g}){ }^{65}$ In Ntshangane $v$ Speciality Metals CC, ${ }^{66}$ Mlambo $\mathrm{J}$ again ascribed the formulation of section 158(1)(g) to inelegant draftmanship and held that: ${ }^{67}$

"[T]he appropriate interpretation of section 158(1)(g) should be that in addition to the court's review power of CCMA arbitration awards, the court is also empowered to review anything else performed in terms of the Act."

This conundrum was resolved in Carephone (Pty) Ltd $v$ Marcus NO, ${ }^{68}$ when Froneman DJP, in a reasoning process similar to Mlambo J's, confirmed that the review of arbitration proceedings must proceed under section 145 of the LRA and not section $158(1)(\mathrm{g})$. $^{69}$

"It must be admitted that the choice of the word 'despite' in section 158(1)(g) is an unhappy one. It allows for an interpretation of section 158(1)(g) as granting a general review power to the Labour Court over any function, act or omission under the LRA, instead of it providing merely for the court's residual powers of review for administrative functions not defined specifically in sections 145 and 158(1)(h). If the latter interpretation is accepted, the provisions of sections $145,158(1)(\mathrm{g})$ and $158(1)(\mathrm{h})$ apply to distinct and different forms of administrative action and do not overlap. If, however, the former interpretation is accepted, the field of application of sections 145 and $158(1)(\mathrm{g})$ do overlap, with the result that the provisions of section 145 become superfluous."

Section 158(1)(g) was subsequently amended by the legislature and "despite" replaced with "subject to". ${ }^{70}$ It is now generally accepted that proceedings for the review of arbitration awards must be instituted in terms of section 145 of the LRA. Since the amendment it is rather the interpretation and application of section 145 that has become the topic of much debate.

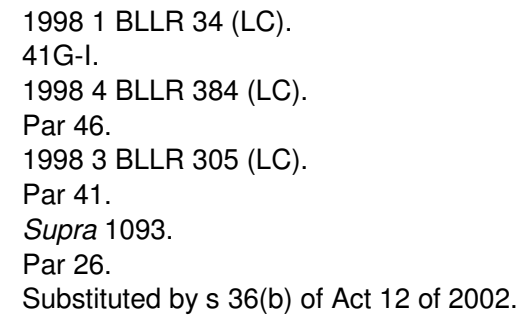




\section{Constitutional justifiability and section 145(2)}

In light of the conclusion that the compulsory arbitration function of the CCMA constitutes administrative action, the proposal followed that section 145 , because of its restrictive grounds for review, fails to give expression to the requirements of the constitutional administrative justice right as contained in section 24(d) of the 1993 Constitution. ${ }^{71}$ In Speciality Metals, Mlambo J, however, held that although section 145 of the LRA does amount to a statutory limitation of the constitutional right to administrative justice, it is a reasonable and justifiable limitation that does not negate the right to administrative justice. ${ }^{72}$ Similarly, in Carephone the court held that there are constitutional constraints on the powers of a commissioner in compulsory arbitration that are not infringed by the wording of section 145 of the LRA: ${ }^{73}$

"The constitutional imperatives for compulsory arbitration under the LRA are thus that the process must be fair and equitable, that the arbitrator must be impartial and unbiased, that the proceedings must be lawful and procedurally fair, that the reasons for the award must be given publicly and in writing, that the award must be justifiable in terms of those reasons and that it must be consistent with the fundamental right to fair labour practices. The provisions of the LRA dealing with arbitration proceedings are not in conflict with these constitutional requirements."

On the contrary, Froneman DJP believed that section 145 was capable of being interpreted in a manner that is consistent with the 1993 Constitution. ${ }^{74}$ According to the court, this entailed an interpretation of section 145, and in particular section 145(2)(a)(iii), which allows the LC to review those arbitration awards in which it was alleged that a commissioner exceeded the constitutional constraints on his power ${ }^{75}$ including where the award is not justifiable in terms of the reasons given.

According to the court, this involved extending the scope of review, ${ }^{76}$ and asking the question whether there is a rational objective basis justifying the connection made by the administrative decision-maker between the material properly available to him and the conclusion he eventually arrived at. ${ }^{77}$ The court did, however, not hold that the constitutional imperatives established independent grounds for review in addition to those already provided for in section 145(2) of the LRA. It is submitted that such a conclusion can be deduced from the following held by the court: ${ }^{78}$

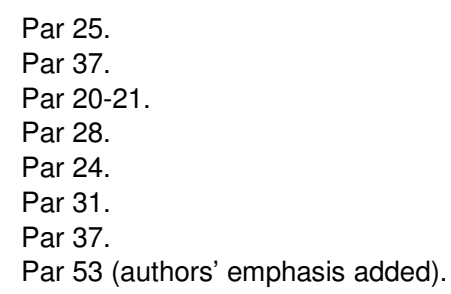


"Accordingly, the only bases for review are (1), that the facts amount to misconduct or gross irregularity or impropriety under section 145(2)(a)(i) to (ii) and section 145(2)(b) of the LRA, or (2), that his actions are not justifiable in terms of the reasons given for them and that he has accordingly exceeded his constitutionally constrained powers under section 145(2)(a)(iii) of the Act."

Read within the context of the judgment as a whole, it is submitted that the court only "extended" the grounds for review in section 145 to the extent of finding that the LC can review an award in terms of section 145(2)(a)(iii) because the award is not justifiable in terms of the reasons given. The court did not hold that justifiability was a separate ground for review, but deduced that the commissioner had exceeded his powers because the award was not justifiable in terms of the reasons given. Justifiability was thus a test to determine whether the commissioner had exceeded his powers in terms of section 145(2)(a)(iii). Such a submission is supported by the following: ${ }^{79}$

"Once again his reasoning was rationally connected to the material before him. His decision and the reasons he gave for it do not support an inference of misconduct, irregularity or impropriety. The decision not to postpone and to continue the proceedings are rationally justifiable in terms of the reasons given for the decision by the commissioner."

In County Fair Foods (Pty) Ltd v CCMA, ${ }^{80}$ a differently-constituted LAC referred to Carephone ${ }^{81}$ and agreed that a commissioner would be exceeding his powers if his award was not justifiable in terms of the reasons given, but held that it could also amount to misconduct in terms of section $145(2)(a)(i)$ or a procedural irregularity in terms of section $145(2)(a)(i i):{ }^{82}$

"The Labour Court is not, however, restricted to applying the provisions of section 145(2)(a)(iii) when reviewing an arbitration award by reason of noncompliance with the constitutional imperatives referred to in paragraph [20] of Carephone. In appropriate circumstances infractions of those imperatives may constitute the commission by the commissioner of a gross irregularity in the conduct of the arbitration proceedings as envisaged in section 145(2)(a)(ii) (or, for that matter, misconduct in relation to his or her duties as arbitrator as envisaged in section 145(2)(a)(i))."

In Toyota South Africa Motors (Pty) Ltd $v$ Radebe, ${ }^{83}$ Nicholson JA accepted Froneman DJP's finding in Carephone that section 145 was the applicable section for the review of an arbitration award. The court, however, had certain misgivings concerning the status of the "justifiability ground" introduced by Carephone. The court expressed its concern as follows: ${ }^{84}$

"I have certain misgivings about whether it constitutes an independent ground upon which an award can be attached. As such it is not part of section 145, which restricts an applicant to misconduct, corruption, gross irregularity and

79 Par 57 (authors' emphasis added).

80199911 BLLR 1117 (LAC).

81 See par 6-7.

82 Par 8.

83 Supra 243.

84 Par 33. 
the excess of powers. I am not sure that Froneman DJP was importing the last-mentioned ground into section 145 and I believe the mention of it in the passage above was in any event an obiter dictum. I have two difficulties with importing this ground into the Act. The first relates to the difference between appeals and reviews and the second relates to the constitutional implications of section 145."

Nicholson JA was of the opinion that, failing a successful constitutionality challenge, section 145 was fully operative and the constitutional provision of justifiability must accordingly be seen in the context of the specific grounds for review in section 145 and not as an independent ground of review. ${ }^{85}$

It is submitted that such an interpretation is correct and in line with the interpretation of Carephone and County Fair Foods as discussed above. In addition, the generally accepted principle that litigants cannot bypass ordinary legislation and rely directly on a constitutional provision in the absence of a constitutional challenge to that ordinary legislation, also lends support to such an interpretation. ${ }^{86}$ Applying this principle, applicants seeking to review arbitration awards will be required to invoke the LRA and section 145, which does not provide for an independent justifiability ground of review, rather than the 1993 Constitution where "justifiability" is derived from. ${ }^{87}$ However, because Carephone attempted to interpret section 145 in conformity with the 1993 Constitution, the requirement of justifiability has been incorporated into the grounds for review in section 145(2). It is submitted that a more extensive interpretation of section 145(2), to the effect that justifiability is an independent ground for review, would have constituted a strained interpretation of that section.

In Shoprite Checkers (Pty) Ltd $v$ Ramdaw $N O{ }^{88}$ the LAC was again offered an opportunity to comment on the correctness of Carephone. Zondo JP referred to Carephone and noted the finding that the ground for review contained in section 145(2)(a)(iii) incorporated the constitutional requirement that administrative action must be justifiable in relation to the reasons given for it. ${ }^{89}$ However, because of Pharmaceutical Manufacturers supra, wherein the $\mathrm{CC}$ had held that public power must be exercised rationally, the court felt compelled to consider whether an award, in so far as it involved the exercise of a public power, was also reviewable based on rationality. Zondo JP stipulated that the question that needed to be answered was whether "rationality" and "justifiability" bore the same meaning, reasoning that if it did, there would be no need to depart from Carephone because the rationality

85 Par 40; see also Cadema (Pty) Ltd v Commission for Conciliation, Mediation and Arbitration (Western Cape Region) 2000 JOL 7425 (LC) par 17.

86 See Sidumo infra par 248-249; and South African National Defense Union v Minister of Defence Chief of the South African National Defense Force 20079 BLLR 785 (CC).

87 National Coalition for Gay and Lesbian Equality v Minister of Home Affairs 20002 SA 1 (CC) par 21; Ex Parte Minister of Safety and Security: in re S v Walters 20024 SA 613 (CC) par 64

88 Supra 1011

89 Par 8. 
ground of review, as it emanated from Pharmaceutical Manufacturers, would already be accommodated in Carephone. ${ }^{90}$ Zondo JP then proceeded to hold as follows: ${ }^{91}$

"There can be no doubt that in Carephone this Court viewed the concept of justifiability as related, at least to some extent, to the concept of rationality but emphasised, correctly in my view, in the context of the fact that it was dealing with section 33 read with item 23 which expressly use the adjective 'justifiable', that it should stick to the term 'justifiable'. In the light of this I am of the view that, although the term 'justifiable' and 'rational' may not, strictly speaking, be synonymous, they bear a sufficiently similar meaning to justify the conclusion that rationality can be said to be accommodated within the concept of justifiability as used in Carephone. In this regard I am satisfied that a decision that is justifiable cannot be said to be irrational and a decision that is irrational cannot be said to be justifiable."

Despite holding that "justifiability" and "rationality" are similar concepts, leading to the inference that there should be no departure from Carephone, the court also found that: ${ }^{92}$

"Irrationality of such decisions is now a ground of review and, quite clearly, the issuing of an arbitration award by a CCMA Commissioner under the Act is an exercise of public power and must, therefore, meet the constitutional requirement of rationality. If an award fails to meet this constitutional requirement, it can be set aside on this ground."

On this reading, which the author submit is in conflict with Carephone, the court seemed to adopt rationality as a ground for review that is severable from the grounds specifically mentioned in section 145 . On the other hand, Zondo JA also held that Carephone stays: ${ }^{93}$

"This appeal can, therefore, be considered on the basis that, as was decided by this Court in Carephone, CCMA awards can be reviewed and set aside if they are not justifiable in relation to the reasons given for them."

Unfortunately, the court did not deal with the question whether rationality, like justifiability, could also be deduced from section 145(2)(a)(iii), except to mention that: ${ }^{94}$

"[l]n determining that the ground of review of justifiability fell within section 145 (2)(a)(iii) of the Act, Carephone in effect held that the time limit set out in section 145 for the bringing of review applications against CCMA awards would apply to that ground of review as well. In this regard it may be thought that, if the ground of review relied upon is not under section 145, the period within which a review on such ground must be launched is a reasonable time from the day of the issuing of the award and not six weeks as prescribed by section 145. If Carephone stands, the question of whether the six weeks period does or does not apply will not arise. Although the reasoning on which this conclusion was based in Carephone is unsatisfactory, there are, in my

90 Par 21.

91 Par 25.

92 Par 26.

93 Par 33.

94 Par 32. 
view, sound policy considerations which justify that we leave Carephone as it is."

\section{Conclusion}

In this paragraph it has been established that the courts regard the CCMA as an organ of state and the rendering of an arbitration award as the commission of an administrative act that is subject to the constitutional imperatives of the administrative justice provision as contained in the 1993 Constitution. However, contrary to litigants' expectations, it has also been established that the courts have not interpreted the restrictive scope of section 145 as falling foul of this constitutional right.

By the time that the question was posed whether reasonableness, as part of the right to just administrative action in the 1996 Constitution, was in some form or another applicable to arbitration award reviews, it had already been established that the making of a CCMA arbitration award constitutes administrative action; that the making of an award is accordingly subject to the constitutional right to administrative justice; that justifiability is a constitutional requirement for just administrative action and that a failure to make a decision that is justifiable in terms of the reasons given may render an award reviewable in terms of section 145 of the LRA. When one reflects upon these principles, it becomes apparent that the CC's judgment in Sidumo is not as ground-breaking as it may at first glance appear. ${ }^{9}$

95 See par 1 in Part 2 of the following edition of Obiter. 